\title{
Ecophysiological studies of two andean forest contrasting species Abatia parviflora and Myrcianthes leucoxyla under Bogotá conditions, Colombia
}

\section{Sara L. Colmenares-Trejos ${ }^{1}$, Luz Marina Melgarejo ${ }^{1{ }^{*}}$ and Hernán Mauricio Romero A'. \\ ${ }^{1}$ Plant physiology and Biochemistry Laboratory, Biology Department, Universidad Nacional de Colombia. Bogotá, Colombia.}

\begin{abstract}
* Corresponding author: Luz Marina Melgarejo. Plant Physiology and Biochemistry Laboratory, Biology Department, Universidad Nacional de Colombia, Bogotá, Colombia. Phone number: (57-1) 3165000 ext 11334. Fax (57-1) 3165310. E-mail: Immelgarejom@unal.edu.co.
\end{abstract}

Received: 23 August 2011; Accepted: 30 January 2012

\begin{abstract}
:
The physiological response of high Andean forest contrasting plants, Myrcianthes leucoxyla, a shadow-facultative heliophyte, and Abatia parviflora, a heliophyte, was studied during the transition from dry season to wet season in Bogotá. Light response curves $(A-P A R)$, water potential $(\Psi w)$, transpiration rate $(E)$, stomatal conductance $(g s)$, leaf soluble protein content and peroxidase activity were measured in this study in a $48 \mathrm{~h}$ cycle. The values for $\mathrm{E}, \mathrm{gs}, \Psi_{\mathrm{w}}$ and $\Psi_{\mathrm{w} \text { predawn }}$ for $M$. leucoxyla were 0.07 to $4.89 \mu \mathrm{g} / \mathrm{cm} \mathrm{s}$, 0.02 to $0.5 \mathrm{~cm} \mathrm{~s}^{-1},-0.025$ to $-1.05 \mathrm{MPa}$, and-0.1 MPa, respectively. For $A$. parviflora $\mathrm{E}, \mathrm{gs}, \Psi_{\mathrm{w}}$ and $\Psi_{\mathrm{w} \text { predawn }}$ were 0.47 to 12.27 $\mu \mathrm{g} / \mathrm{cm} \mathrm{s}, 0.17$ to $1.42 \mathrm{~cm} \mathrm{~s}^{-1},-0.05$ to $-0.3 \mathrm{MPa}$ and $-0.075 \mathrm{MPa}$, respectively. A. parviflora presented a tendency of stomatal closure at midday and peroxidase activity increased with the increasing solar radiation, this did not occur in $M$. leucoxyla. The light compensation point $\left(I_{c}\right)$ in $A$. parviflora was about $18.10 \mu$ mol photon $\mathrm{m}^{-2} \mathrm{~s}^{-1}$, typical for a heliophyte plant; while for $M$. leucoxyla it was $8.87 \mu \mathrm{mol}$ photon $\mathrm{m}^{-2} \mathrm{~s}^{-1}$, slightly above the maximal reported values for shadow plants and under the minimal reported values for light plants. The lowest photosynthetic rate $(\mathrm{A})$ of $M$. leucoxyla $\left(2.8 \mu \mathrm{mol} \mathrm{CO}{ }_{2} \mathrm{~m}^{-2} \mathrm{~s}^{-1}\right)$ in comparison with $A$. parviflora $(7.4 \mu \mathrm{mol}$ $\left.\mathrm{CO}_{2} \mathrm{~m}^{-2} \mathrm{~S}^{-1}\right)$ is compensated with a better photonic use efficiency $\left( \pm 0.7792 \mathrm{~mol} \mathrm{C} \mathrm{mol}^{-1}\right)$.
\end{abstract}

Key words: A-PAR curves; Gas exchange; Heliophyte; Shadow plant; Water potential

\section{INTRODUCTION}

Photosynthesis and stomatal conductance studies of tropical tree species under various conditions are considered of great importance to understand the role of the tropical forest in regional water and carbon cycles, considering that abiotic factors such as light, seasonal variations of temperature and water can drastically influence plant responses (Silva et al., 2010). Analysis of physiological responses to seasonal variation is necessary to identify the interaction potentials between tropical forests and climate change (Hogan, 1988). Ecophysiological attributes of plants give valuable information about the functioning of the species, they give information about the properties of the ecosystem too (Lavorel and Garnier, 2002).

Wild species evolved and established naturally in a given place, present diverse and unique adaptations to the conditions of their surroundings; the kind of response is a feature of each 
species and its inner acclimation and plasticity phenomena. Increases in temperature, relative humidity and precipitation rates reductions and also the increments in atmospheric $\mathrm{CO}_{2}$ and average radiation, can induce species vulnerability (LiraSaade, 1996; Vozari-Hampe et al., 1992).

In this work was evaluated the gas exchange and the water potential in the transition between dry to wet season (March-April 2009), under the typical conditions found in Bogotá, of $M$. leucoxyla and $A$. parviflora, that are native species of the tropical rainforest (Zárate et al., 2004).

M. leucoxyla (Myrtaceae) is a tree with small leaves (< $2 \mathrm{~cm}$ width) of variable forms: sun leaves are elliptic, short and coriaceus and shadow leaves are lanceolate, elongated and chartaceus-coriaceus. M. leucoxyla is a shadow plant and optional heliophilous. It is a species of foot slopes and ravines, is an atmospheric high humidity bioindicator and is used in the restoration of Andean native ecosystems (Mahecha, 2004).

A. parviflora (Flacourtiaceae) has simple and opposite leaves (>15 cm length), lanceolated, tomentose and whitish on the underside. It is a strictly heliophilous plant and has a wide altitudinal distribution range (accompanied by a great morphological variation). This specie is used for restoration of natural sources of water and ravine forest (Mahecha, 2004).

\section{MATERIALS AND METHODS}

The study was carried out in M. leucoxyla and $A$. parviflora trees located in the arboretum of Universidad Nacional de Colombia, Bogotá city. For each species three outerleaves completely expanded from the middle stratum branch of the tree canopy were sampled. Photosynthetic light response was measured with an infrared gas analyzer (IRGA - LI-6400, LI-COR Biosciences, Inc., Lincoln, NE) and with a quantity of light of $1000 \mu \mathrm{mol}$ photons $\mathrm{m}^{-2} \mathrm{~s}^{-1}$ and a chamber temperature of $20^{\circ} \mathrm{C}$ to avoid variations on the leaf stomatal conductance. The reference $\mathrm{CO}_{2}$ was about $400 \mu \mathrm{mol} \mathrm{CO}$ mol- ${ }^{-1}$ and flux rate $150 \mu \mathrm{mol} \mathrm{s}^{-1}$. Measurements were made between 09:00h and 11:30h.

The light photosynthesis response model was formulated based on a hyperbolic rectangular model (Givnish, 1988; Long and Hällgren, 1993) and calculations were made using the Statistix 9.0 program, according to equation 1 :

Eq. 1. ${ }^{A}=\frac{A_{\text {SaA } P A R}}{(K+P A R)}-R d$ (Kubiske and Pregitzer, 1996).
Where $A_{\text {sat }}$ is the photosynthesis rate at the saturation point or net photosynthesis, $\mathrm{K}$ is the light saturation constant (defined as $1 / 2$ of the light saturation point), and $R d$ is the dark respiration rate (Kubiske and Pregitzer, 1996). The light compensation point, Ic, is calculated through the model as well as the quantum photosynthetic yield $(\Phi)$, determined as the initial slope above the light compensation point.

Every two hours in a 48h cycle, taking the same number of leaves at the same tree stratum, the plant water potential, $\Psi w(\mathrm{MPa})$, using the pressure chamber method (Pms-650, Corvallis, Oregon, USA); transpiration rate, $\mathrm{E}$, and stomatal conductance, gs using a steady state porometer (Li-1600, Lincoln, Nebraska) were measured. The first measurement was made at 04:00h.

The environmental measurements such as relative humidity percentage (\%HR) and photosynthetic active radiation (PAR) were monitored constantly with a portable weather station HOBO (Coltain 2003-2006). Soil water potential was measured with a tensiometer located one meter from the weather station. Atmosphere water potential was calculated according to equation 2 :

$$
\text { Eq. } 2 \quad \Psi=\frac{\mathrm{RT}}{\mathrm{V}} \ln \frac{\mathrm{HR}}{100} ; 0.4608 \mathrm{~T} \ln \frac{\mathrm{HR}}{100}
$$

During the cycle, leaf samples were collected, frozen with liquid nitrogen and stored at $-20^{\circ} \mathrm{C}$ for posterior peroxidase activity (EC 1.11.1.7) and protein content analyses.

Enzymatic activity of peroxidase was measured using the ortho-dianisidine/peroxide modified method (Dalisay and Kúc, 1995; Kireyko et al., 2006). In pre-chilled mortars, $0.5 \mathrm{~g}$ of frozen tissue was macerated with liquid nitrogen and 0.25 $\mathrm{g}$ of polivinylpolipyrrolidone (PVPP) - Sigma). The resulting powder was collected in Falcon tubes and washed twice with $2 \mathrm{ml}$ of cold acetone to eliminate pigments from the tissue, and each time the mixture was shaken for 15 minutes at $4^{\circ} \mathrm{C}$ and then centrifuged at $6000 \mathrm{rpm}, 15$ minutes and $4^{\circ} \mathrm{C}$. The supernatant was then extracted. To the resultant pellet $2.5 \mathrm{ml}$ of sodium phosphate buffer $0.1 \mathrm{M}, \mathrm{pH} 6.5$ and polyvinylpirrolidone $1 \%$ (PVP-40, Sigma) v/v were added. This reaction mix was placed in shaker at $220 \mathrm{rpm}$ for $1 \mathrm{~h}$ at $4^{\circ} \mathrm{C}$, and then centrifuged at $6000 \mathrm{rpm}$ for $1 \mathrm{~h}$ at $4^{\circ} \mathrm{C}$. The crude extract was dialyzed using a PM10 pore size membrane for $92 \mathrm{~h}$ at $4^{\circ} \mathrm{C}$ with constant agitation, doing exchanges of ionized and distillated $\mathrm{H}_{2} \mathrm{O}\left(\mathrm{H}_{2} \mathrm{Odd}\right)$ each $12 \mathrm{~h}$, for two days. 
The foliar soluble protein content was measured from $15 \mu \mathrm{l}$ of dialyzed extract. They were mixed with $200 \mu \mathrm{l}$ of Bradford's kit dye reagent (BIO-RAD Protein Assay Kit II) and $785 \mu \mathrm{l}$ of sodium-phosphate buffer $(0.1 \mathrm{M}, \mathrm{pH} 6.5)$. The reference used was sodium-phosphate buffer $(0.1 \mathrm{M}, \mathrm{pH} 6.5)$ without extract. The variation in color was measured at 595 nm with a Bio-Rad Smart Spec TM 3000 spectrophotometer. The calibration curve was made with a stock $(1 \mathrm{mg} / \mathrm{mL})$ of lyophilized Bovine Serine Albumin (BSA)

Different protocols for peroxidase activity (EC 1.11.1.7) were proved for both species. For $A$. parviflora the reaction mixture was $10 \mu \mathrm{l}$ of $0.5 \%$ o-dianisidine diluted in methanol, $10 \mu \mathrm{l}$ of $30 \% \mathrm{H}_{2} \mathrm{O}_{2}, 20 \mu \mathrm{l}$ of tissue extract and $500 \mu \mathrm{l}$ of 0.1 $\mathrm{M}$ sodium-phosphate buffer ( $\mathrm{pH}$ 6.5). The determination of enzyme activity was performed by measuring the change in optical density during 60seconds, every ten seconds, at 436 nm with a Bio-Rad Smart Spec TM 3000 spectrophotometer. Units of enzyme activity were defined as the amount of enzyme that catalyzes the conversion of $1 \mu \mathrm{mol}$ of substrate per minute. The specific enzyme activity was calculated as enzyme activity / mg protein.

A

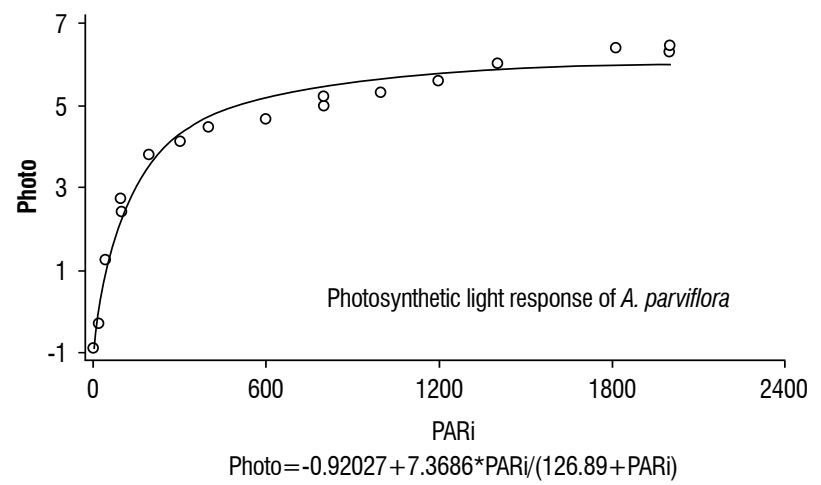

For $M$. leucoxyla the reaction mixture was $40 \mu \mathrm{l}$ of $0.5 \%$ 0-dianisidine in methanol, $40 \mu \mathrm{l}$ of $30 \% \mathrm{H}_{2} \mathrm{O}_{2}, 100 \mu \mathrm{l}$ of tissue extract and $360 \mu \mathrm{l}$ of $0.1 \mathrm{M}$ sodium-phosphate buffer $\mathrm{pH} 6.5$. Once prepared, the reaction mixture was incubated for $1 \mathrm{~h}$ at $37^{\circ} \mathrm{C}$ and the absorbance was measured at $436 \mathrm{~nm}$. The enzyme activity was calculated using the molar extinction coefficient of 0-dianisidine $\mathrm{cm}^{2} / \mathrm{mol} 8.3$ (Bergmeyer et al., 1974). The specific enzyme activity was calculated as enzyme activity/mg protein.

The results were statistically analyzed using the Statistix 9.0 program.

\section{RESULTS}

The equation of $A$. parviflora light curve (Eq. 3) is $A=\frac{7.36 \mathrm{PAR}}{(126.89+\mathrm{PAR})}-0.9202$ with a $\mathrm{R}^{2}=0.99$ and for $M$. leucoxyla was (Eq. 4) $A=\frac{2.786 \mathrm{PAR}}{(50.709+\mathrm{PAR})}{ }^{-0.4149}$ with $R^{2}=0.96$ (Figure 1). Light compensation point (IC), light saturation point (Is), net photosynthesis rate $(A)$, photosynthetic quantum yield $(\Phi)$ and net respiration $(R)$ for both species are presented in Table 1.

Figure 1. Photosynthetic light response of $A$. parviflora (A) and $M$. leucoxyla (B). Where Photo $=\mathrm{A}_{\text {sat, }}$, photosynthesis rate at light saturation point $\left(\mu \mathrm{mol} \mathrm{CO}_{2} \mathrm{~m}^{-2} \mathrm{~s}^{-1}\right)$; PARi $=$ photosynthetic active radiation $\left(\mu \mathrm{mol}\right.$ photon $\left.\mathrm{m}^{-2} \mathrm{~s}^{-1}\right)$.

Table 1. Light compensation point (IC), light saturation point (IS), photosynthesis net rate (A), photosynthetic quantum yield or photon use efficiency ( $\Phi)$ and respiration (Rd) for $A$. parviflora and $M$. leucoxyla

\begin{tabular}{ccc}
\hline Specie/Parameter & M. leucoxyla & A. Parviflora (Heliophilic) \\
\hline Ic $\left(\mu \mathrm{mol}\right.$ photon $\left.\mathrm{m}^{-2} \mathrm{~s}^{-1}\right)$ & (Umbrophilic - Facultative Heliophilic) & \pm 18.1 \\
Is $\left(\mu \mathrm{mol}\right.$ photon $\left.\mathrm{m}^{-2} \mathrm{~s}^{-1}\right)$ & \pm 8.87 & $253.8 \pm 18.7$ \\
$\mathrm{~A}\left(\mu \mathrm{mol} \mathrm{CO} \mathrm{m}^{-2} \mathrm{~s}^{-1}\right)$ & $101.4 \pm 14.5$ & $7.37 \pm 0.27$ \\
$\Phi\left(\mathrm{mol} \mathrm{C} \mathrm{mol}^{-1}\right)$ & $2.79 \pm 0.20$ & \pm 0.03018 \\
$\operatorname{Rd}\left(\mu \mathrm{mol} \mathrm{CO} \mathrm{m}^{-2} \mathrm{~s}-1\right)$ & \pm 0.7792 & $-0.92 \pm 0.26$ \\
\hline
\end{tabular}


For M. leucoxyla, transpiration (E) and stomatal conductance (gs) were ranged from $0.07 \mu \mathrm{g} / \mathrm{cm} \mathrm{s}^{-1}$ to $4.89 \mathrm{~g} / \mathrm{cm} \mathrm{s}^{-1}$, and from $0.02 \mathrm{~cm} \mathrm{~s}^{-1}$ to $0.5 \mathrm{~cm} \mathrm{~s}^{-1}$, respectively. Leaf water potential ( $\left.\Psi \mathrm{w}\right)$ varied between $-0.025 \mathrm{MPa}$ and $-1.05 \mathrm{MPa}$, with a marked drop towards midday (Figure 2). Predawn $\Psi w(04: 00 \mathrm{~h})$ was $-0.1 \mathrm{MPa}$ and minimum $\Psi$ w (12:00h) was $-0.550 \mathrm{MPa}$.

For $A$. parviflora, E ranged from $0.47 \mu \mathrm{g} / \mathrm{cm} \mathrm{s}^{-1}$ to 12.27 $\mu \mathrm{g} / \mathrm{cm} \mathrm{s}^{-1}$, and gs from $0.17 \mathrm{~cm} \mathrm{~s}^{-1}$ to $1.42 \mathrm{~cm} \mathrm{~s}^{-1}$. $\Psi \mathrm{w}$ was between $-0.05 \mathrm{MPa}$ and $-0.3 \mathrm{MPa}$ (Figure 2). Predawn $\Psi \mathrm{w}$ was $-0.075 \mathrm{MPa}$ and at $12: 00 \mathrm{h \Psi w}$ was $-0.275 \mathrm{MPa}$.

$\Psi_{\mathrm{w}}$ (MPa) Abatiaparviflora

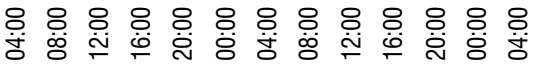

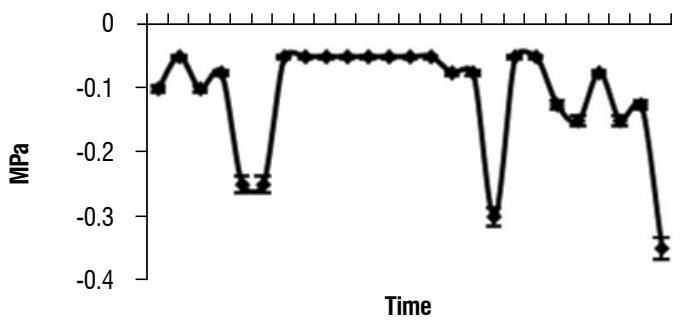

For $A$. parviflora protein values ranged between 0.020 and $0.397 \mathrm{mg}$ protein / $\mathrm{g}$ of fresh plant material (data not shown). POD activity was higher in PAR peak hours (10:00 - 14:00 h) (Figure 3).

On the other hand, M. leucoxyla protein values ranged between 0.022 and $0.810 \mathrm{mg}$ protein $/ \mathrm{g}$ of plant tissue (data not shown). Unlike A. parviflora, there was not a relationship between POD enzyme activity and the measured environmental parameters (Table 2).

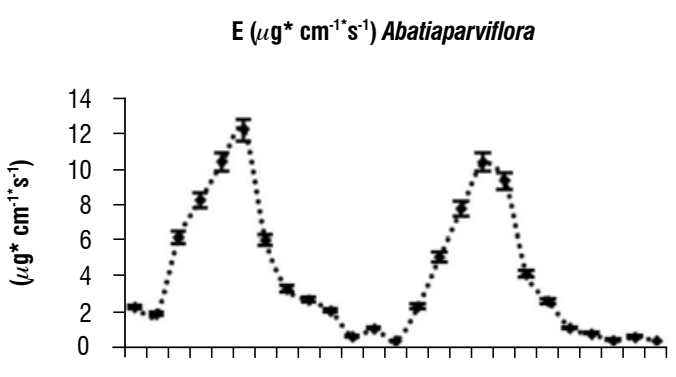

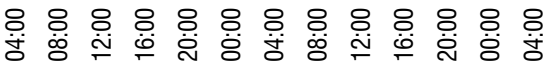

Time
$\Psi_{\mathrm{w}}(\mathrm{MPa})$ Myrcianthes leucoxyla

务

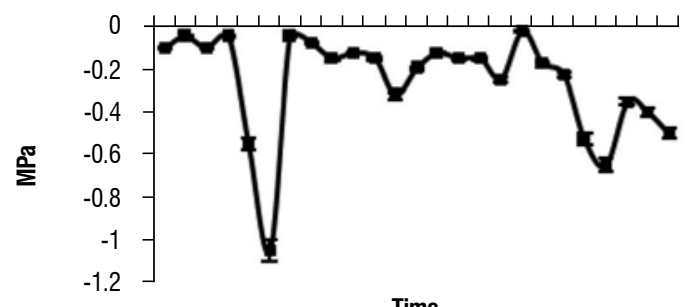

Time
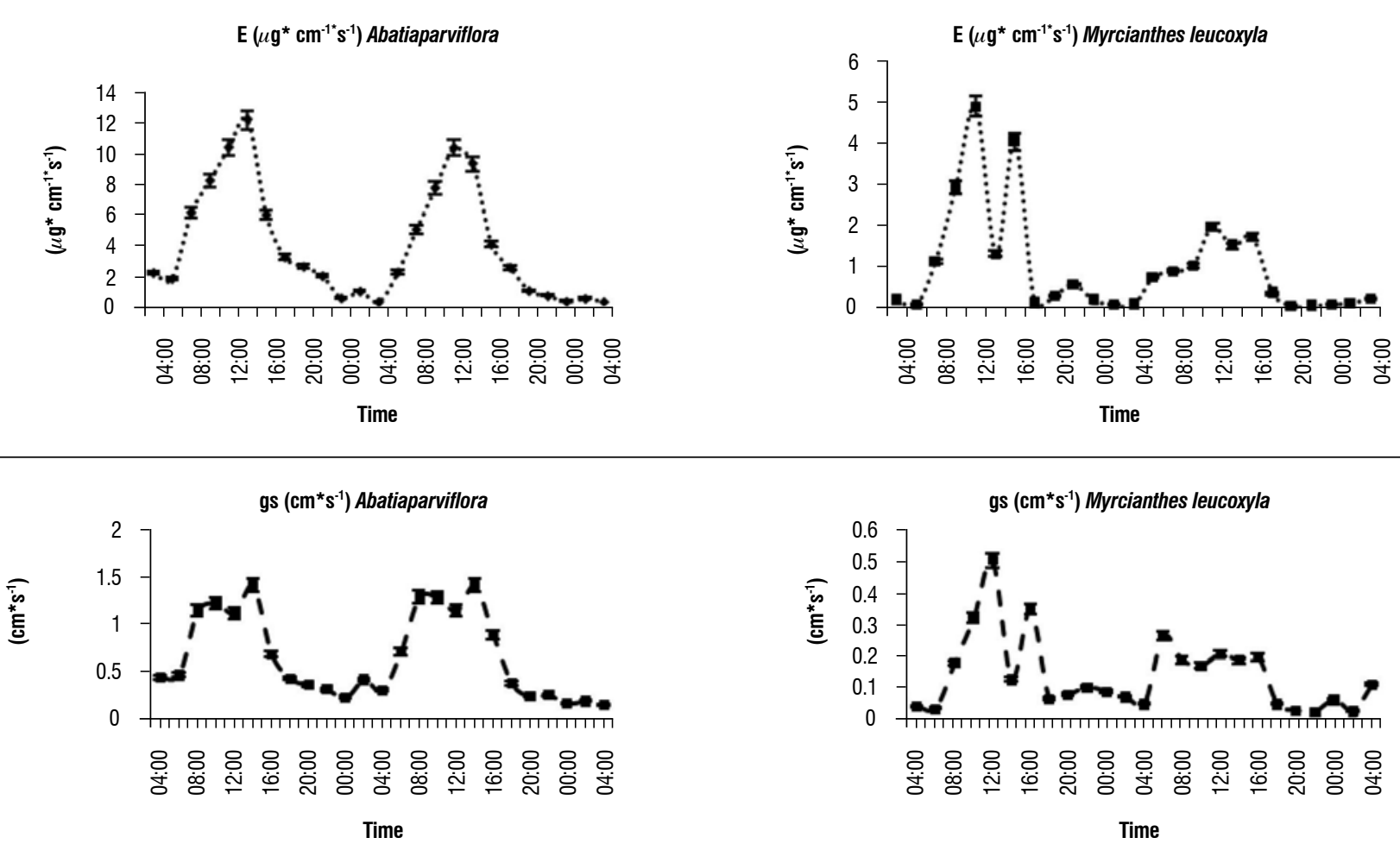

Figure 2. Water potential, transpiration and stomatal conductance of $A$. Parviflora and M. leucoxyla during a cycle of $48 \mathrm{~h}(\mathrm{n}=3)$. 

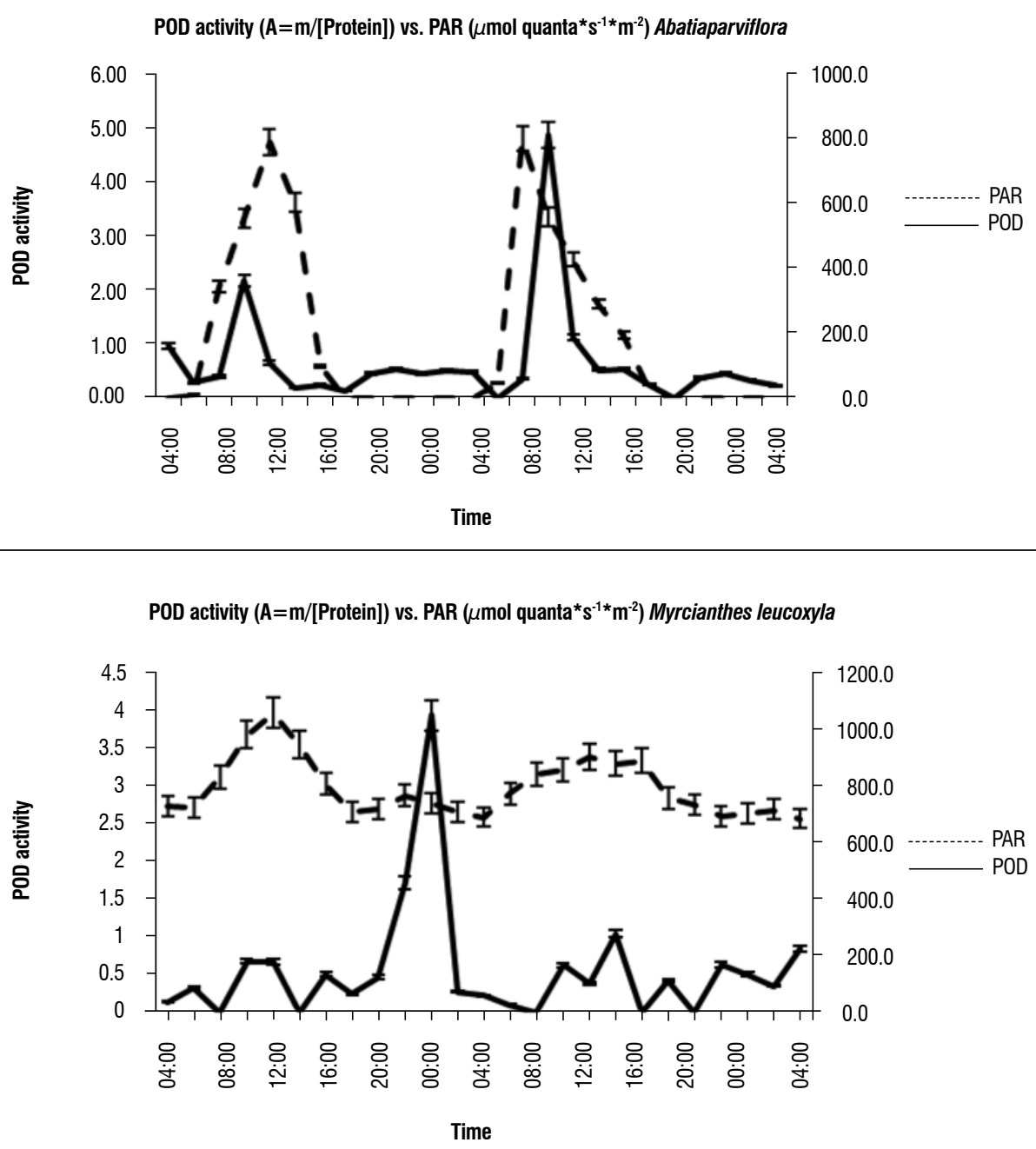

Figure 3. Peroxidase activity in A. Parviflora and M. leucoxyla related with changes in the light intensity during the measurement time $(n=3)$.

Table 2. Environmental parameters during the sample collecting and measurement period. Bogotá - Colombia, arboretum, Universidad Nacional de Colombia.

\begin{tabular}{cccccc}
\hline HOUR & $\mathrm{T}^{\circ}(\max )$ & $\% \mathrm{HR}(\mathrm{max})$ & PAR $\left(\mu \mathrm{mol}\right.$ quanta* $\left.\mathrm{s}^{-1 *} \mathrm{~m}^{-2}\right)(\mathrm{max})$ & VPD & $\Psi$ atm MPa $(\mathrm{max})$ \\
\hline $04: 00$ & 13 & 77 & 0 & 0.835 & -66.0 \\
$06: 00$ & 13 & 72 & 45 & 0.848 & -53.4 \\
$08: 00$ & 16 & 68 & 798 & 1.069 & -66.1 \\
$10: 00$ & 18 & 56 & 557 & 1.279 & -79.5 \\
$12: 00$ & 21 & 46 & 786 & 1.493 & -128.6 \\
$14: 00$ & 21 & 48 & 601 & 1.441 & -113.7 \\
$16: 00$ & 16 & 65 & 193 & 1.080 & -118.6 \\
$18: 00$ & 15 & 64 & 21 & 1.031 & -99.8 \\
$20: 00$ & 15 & 64 & 0 & 0.980 & -87.7 \\
$22: 00$ & 13 & 73 & 0 & 0.835 & -77.0 \\
$00: 00$ & 13 & 77 & 0 & 0.820 & -36.6 \\
$04: 00$ & 13 & 75 & 0 & 0.832 & -43.3 \\
\hline
\end{tabular}




\section{DISCUSSION}

Sun plants have a higher photosynthetic capacity than shadow plants (Lichtenthaler and Burkart, 1999). Shadow plants invest on strategies for better light capture and use of light (Sarijeva et al., 2007) and reduction in the respiration rate (Bjorkman, 1981). In addition, one of the most notorious differences between sun and shadow plants is the light compensation point, Ic value, that for sun plants is in a range of 10 to $20 \mu \mathrm{mol} \mathrm{m} \mathrm{m}^{-2} \mathrm{~s}^{-1}$, while for shadow plants varies between 1 to $5 \mu \mathrm{mol} \mathrm{m}{ }^{-2} \mathrm{~s}^{-1}$ (Larcher, 2003). Thus, A. parviflora Ic values were close to the expected for strictly heliophilous plants, and for M. leucoxyla, Ic values are above the maximum reported for shadow plants, and under the minimum reported for sun plants, demonstrating their umbrophilic and facultative heliophilic feature.

Low Ic values in shadow plants are related with low respiration rate (Larcher, 2003). It seems to represent a basic adaptation that allows shadow plants survive in light deficient environments. M. leucoxyla presents Rd values that are less than half of the measured values for $A$. parviflora and also, a lower photosynthetic rate was found in $M$. leucoxyla than in $A$. parviflora, confirming what was reported in the literature for these kinds of plants.

The lowest A in M. leucoxyla, compared with A. parviflora, is compensated by a better $\Phi$. Literature reports shows that $\Phi$ varies between 0 and 1 , being zero when none of the absorbed energy is used for photosynthesis and one when all the energy absorbed is used (Kubiske and Pregitzer, 1996; Larcher, 2003; Moreno, 1994). Table 1 shows that the highest value of $\Phi$ is presented by $M$. leucoxyla, meaning that the number of absorbed photons is more efficient to $\mathrm{CO}_{2}$ assimilation, facilitating their existence in shady environments. It also has a typical Ic value for shade leaves of evergreen trees, where the reported range is between 2-10 $\mu$ mol photons $\mathrm{m}^{-2} \mathrm{~s}^{-1}$ (Kubiske and Pregitzer, 1996; Larcher, 2003; Moreno, 1994). In turn, the Is value is also characteristic of shade leaves, being between $100-150 \mu \mathrm{mol}$ photons $\mathrm{m}^{-2} \mathrm{~s}^{-1}$. High quantum efficiency is also typical of leaves that grow in shady environments, and $\mathrm{Rd}$ the value (of 0.41 ) is similar to that reported for canopy and emergent plants in shaded environments (Moreno, 1994). Therefore, M. leucoxyla is a plant with minimum of energy requirements to supply its needs. In $A$. parviflora, as shown in Table 1, Ic is similar to that reported for plants growing in higher light environments, and decreases with the decrease in light intensity (Moreno, 1994). It also presents an Ic value typical of sun leaf evergreen trees. The data suggest that $A$. parviflora could change its photosynthetic response under different light environments; the ability to increase their rate of photosynthesis in illuminated environments being a typical response of sun-loving plants (Moreno, 1994). The value of $\mathrm{Rd}$, as reported in the literature for tropical forest species, is typical of sun-loving species (Moreno, 1994).

During the sampling time it was observed that with increasing temperature and PAR and the reduction of the atmospheric relative humidity, the atmospheric water potential increases (Table 2), which is also related to pressure deficit VPD vapor, thus the stomatal conductance (gs) is greater in the two species, as the $E$ too (Figure 2). The temperature rise of plants under the sun, due to excessive capture of light, is balanced by transpiration, reducing the boundary layer resistance (Givnish, 1984) and increasing energy dissipation as heat (no photochemical yield fluorescence - NPQ) (Behera et al., 2003). To stay physiologically active plants needs to adjust the transpiration with the absorption of water (Humphreys et al., 2006) and must be able to keep this balance through adjustment between the availability of water, the rate of leaf water loss and the capacity of the transport system to take water from the ground up to the leaves and to withstand changes in transpiration or extreme stress generated in the xylem due to water loss (Bhaskhar and Ackerly, 2006). The results show a marked tendency to stomatal closure in A. parviflora at noon, not being as marked in M. leucoxyla, confirming the results reported in the literature.

Soil water potential was near to zero due the rains presented during the sample time, keeping the soil in field capacity in a range of -0.2 to $0.0 \mathrm{MPa}$. The difference between predawn and minimal water potential for $A$. parviflora was lower than the difference observed in $M$. leucoxyla. These behavior of $\Psi w$ towards noon (Figure 2) is associated with the loss of water by transpiration that rises when leaves needs to regulate their temperature, by the diffusion of water vapor in the hours when the temperature increases, the regulation of gas exchange being a mechanism used by the plant to reduce the potentiality of possible damages (Cadena et al., 1983). Since the leaf water availability has not been a limiting factor, there is a correlation between received solar radiation and the amount of transpired water because the solar radiation gives the plant enough energy to vaporize the water 
that is transported by the xylem. The increase in the leaves' resistance to diffusion (stomatal closure) suggest a lack of correlation between those parameters (Aguirre-Medina, 2001; Reigosa et al., 2004) because the stomatal closure rises with increasing of water vapor pressure deficit and the loss of turgor (Aguirre-Medina, 2001; Brodribb et al., 2003; Larcher, 2003).

Moreover, throughout evolution, plants have developed some strategic morphological characteristics to allow them to carry out gas exchange with minimal loss of water. Some of these features are the presence of impermeable cuticles, the presence of trichomes and the responsiveness of stomata to stressful environmental conditions such as reduced soil water availability and air temperature changes. Johnson (1975) reported that there is not a well-defined pattern of distribution of trichomes and that they can form large groups common in texture, orientation, density, size and color. He also states that the role of trichomes is in helping with the system water economy, as observed in plants of arid and semiarid climates that have abundant pubescence. $A$. parviflora presents high leaf pubescence, with the underside covered by stellate whitish trichomes, which can be considered as an adaptive mechanism that allows the plant to reflect sunlight and decrease the temperature of the foliar lamina (Cadena-Iñiguez et al. 1983).

The peroxidase activity in $A$. parviflora increases with the increasing of solar radiation (Figure 3). This plant is a strictly heliophilic species, capable of inhabiting spaces bare of vegetation and thus getting exposed to direct solar radiation that can generate a high production of free radicals. The plant must also have an active antioxidative mechanism to protect itself from free radicals, being different to the activity presented in $M$. leucoxyla (Figure 3), a plant not necessarily exposed to high solar radiation.

Antioxidants play important roles as free radical scavengers, stabilizers and protectors of DNA and proteins against oxidative stress (Apel and Hirt, 2009). Many metabolites do not show constitutive expression, but depend on the specific environmental background, as is observed under the context of these two species. This is probably because the environment can modify gene expression by changing the development programs of the plant and generate special patterns of metabolism and morphogenesis (Bohnert and Shevelev, 1998).
Based on the results, $M$. leucoxyla is a typical shadow plant, in which its photosynthetic capacity is greatly reduced when increases the light intensity, and increases when increase the shadow, which gives an ecological advantage in shaded environments. On the other hand, A. parviflora presents typical trends of sun plants, their features confirms its position as a forerunner of preclimatic states in ecological processes of ecological succession and hence its usefulness in restoration processes in degenerated city environments.

Acknowledgments: This work was funded by the Division of Research of the National University of Colombia, Bogotá (DIB). We acknowledge the Corporation Research Centre for Oil Palm, CENIPALMA, by the collaboration with the Ioan of Infrared Gas Analyzer (IRGA).

\section{REFERENCES}

Aguirre-Medina J F (2001) Regulación del intercambio de gases y relaciones hídricas en Chayote (Sechium Edule (Jacq.) Swartz). Serie Horticultura. Revista Chapingo. 7:21-35.

Apel K, Hirt H (2004) Reactive Oxygen Species: Metabolism, Oxidative Stress, and Signal Transduction. Annu. Rev. Plant Biol. 55:373-99.

Behera RK, Choudhury NK (2003) High irradiance-induced changes in carotenoid composition and increase in non-photochemical quenching of Chl a fluorescence in primary wheat leaves. J. Plant Physiol. 160:1141-1146.

Bhaskar R, Ackerly DD (2006) Ecological relevance of minimum seasonal water potentials. Physiol. Plant. 127:353-359.

Bergmeyer HU, Gawehn K, GrassI M (1974) Methods Of Enzymatic. Analysis. Vol. 1, $2^{\mathrm{a}}$ edición. Weinheim, Germany, Verlag Chemie. 574 p.

Björkman 0 (1981) Responses to different quantum flux densities. In: O.L. Lange, P.S. Nobel, C.B. Osmond \& H. Ziegler (Eds.), Physiological Plant Ecology I. Responses to the Physical Environment, Springer, Heidelberg, New York. p. 57-107.

Brodribb TJ, Holbrook NM, Edwards EJ, Gutiérrez MV (2003) Relations between stomatal closure, leaf turgor and xylem vulnerability in eight tropical dry forest trees. Plant Cell Environ. 26:443-450.

Bohnert HJ, Sheveleva E (1998) Plant stress adaptations: making metabolism move. Curr. Biol. 1:267-274.

Cadena-Iñiguez J, Ruiz-posadas LM, Trejo-López C, Sánchez-García V, Willmer CM (1983) Stomata. Longman Group Limited. London, England. pp. 1-6.

Dalisay RF, Kúc JA (1995) Persistence of reduced penetration by Colletotrichum legenarium into cucumber leaves with induces systemic resistanced and its relation to enhanced peroxidase and chitinase activities. Physiol. Mol. Plant Pathol. 47:336-341

Givnish TJ (1984) Leaf and canopy adaptations in tropical forests. In: E. Medina, H.A. Mooney \& C. Vasquez-Yanes (Eds.), Physiological Ecology of Plants in the Wet Tropics. Dr. Junk. The Hague. p. 51-84.

Givnish TJ (1988) Adaptation to Sun Vs. Shade: A Whole-Plant Perspective. Austral J Plant Physiol. 15:63-92.

Hogan KP (1988) Photosynthesis in Two Neotropical Palm Species. Funct Ecol 2(3): 371-377. 
Humphreys MW, Yadav RS, Cairns AJ, Turner LB, Humphreys J, Skøt L (2006) A Changing Climate for Grassland Research. New Phytol. 169:9-26 Johnson HB (1975) Plant Pubescence: an ecological perspective. Bot. Rev. 41:233-268.

Kireyko AV, Veselova IA, Shekhovtsova TN (2006) Mechanisms of peroxidase oxidation of 0 -dianisidine, 3,3',5,5'-tetramethylbenzidine, and o-phenylenediamine in the presence of sodium dodecyl sulfate. Russ $\mathrm{J}$ Bioorgan Chem. 32:71-77.

Kubiske ME, Pregitzer KS (1996). Effects of elevated $\mathrm{CO}_{2}$ and light availability on the photosynthetic light response of trees of contrasting shade tolerance. Tree Physiol. 16: 351-358

Larcher W (2003) Physiological Plant Ecology. Ecophysiology and Stress Physiology of Functional Groups. Springer 4th Edition. Germany. 513P.

Lavorel, S, Garnier, E. 2002. Predicting changes in community composition and ecosystem functioning from plants traits: revisiting the Holy Grail. Funct Ecol. 16: 545-556.

Lichtenthaler HK, Burkart S (1999) Photosynthesis and high light stress. Bulg. J. Plant Physiol. 25:3-16

Lichtenthaler HK, Burkart S (1999) Photosynthesis and high light stress. Bulg. J. Plant Physiol. 25(3-4): 3-16.

Lira-Saade R (1996) Chayote. Sechium edule (Jacq.) Sw. Promoting the Conservation and Use of Underutilized and Neglected Crops. Institute of Plant Genetics and Crop Plant Research, Gatersleben/International Plant Genetic Resources Institute, Rome, Italy. 57 p.

Long SP, Hällgren JE (1993) Measurements of C02 assimilation by plants in the field and the laboratory. pp.129-167. In: Hall DO, Scurlock JMO, BolhàrNordenkampf HR, Leegood RC, Long SP (eds) Photosynthesis and production in a changing environment. A field and laboratory manual. Chapman \& Hall, London, England. 464P.

Mahecha E (2004) Vegetación del Territorio CAR, 450 Especies de sus Llanuras y Montañas, Corporación Autónoma Regional. Edición, p. 871.

Moreno F (1994). Fotosíntesis en Plántulas de Sajo (Campnosperma Panamensis) y Cuangare (Otoba Gracilipes) Bajo Diferentes Ambientes Lumínicos. Crónica Forestal y del Medio Ambiente, Universidad Nacional de Colombia. Diciembre. 12 (1): 1-8.

Sarijeva G, Knapp M, Lichtenthaler HK (2007) Differences in photosynthetic activity, chlorophyll and carotenoid levels, and in cholorophyll fluorescence parameters in green sun and shade leaves of Ginkgo and Fagus. J. Plant Physiol. 164: 950-955.

Silva AS, Oliveira JG, Da Cunha M, Vitória AP (2010) Photosynthetic performance and anatomical adaptations in Byrsonima sericea DC under contrasting light conditions in a remnant of the Atlantic forest. Braz. J. Plant Physiol. 22:245-254.

Reigosa MJ, Pedrol N, Sánchez A (2004) La Ecofisiología vegetal, una ciencia de síntesis. Universidad de Vigo. International Thomson Editores. España. $1216 p$.

Vozari-Hampe MM, Viegas C, Saucedo C, Rosseto S, Manica GG, Hampe OG (1992) A lectin from Sechium edule fruit exudate. Phytochemistry 31:14471480.

Zárate E, Belalcázar LC, Echeverry D, Clappier A (2004) 9th Int. Conf. on Harmonisation within Atmospheric Dispersion Modeling for Regulatory Purposes: air quality modeling over Bogotá city. Air and soil pollution laboratory (LPAS) - Swiss Federal Institute of Technology (EPFL), Lausanne, Switzerland; Environmental Engineering Department - Universidad de los Andes, Bogotá, Colombia. P. 5. 